\title{
Geochemical characteristics of Callovian- Oxfordian carbonates in Samandepe gas field, Amu Darya Basin, Turkmenistan
}

\author{
Zheng Rongcai ${ }^{1 *}$, Li Yun ${ }^{1}$, Wu Lei ${ }^{2}$, Wu Xianzhong ${ }^{2}$, Li Fengjie ${ }^{1}$ and \\ Niu Gang ${ }^{2}$
}

\author{
${ }^{1}$ State Key Laboratory of Oil and Gas Reservoir Geology and Exploitation, Chengdu University of Technology, Chengdu \\ 610059, China \\ ${ }^{2}$ CNPC, Amu Darya Turkmenistan
}

(C) China University of Petroleum (Beijing) and Springer-Verlag Berlin Heidelberg 2011

\begin{abstract}
The Callovian-Oxfordian carbonate reservoirs are the most important hydrocarbon reservoir in the Samandepe gas field, Amu Darya basin, Turkmenistan. Based on the analysis of $\mathrm{Fe}, \mathrm{Mn}$ and $\mathrm{Sr}$ trace elements, and carbon, oxygen and strontium isotopes, the genesis and evolutionary characteristics of the carbonate reservoirs were studied, and the conclusions were follows: 1) Sustained transgressiveregressive cycles played an important role during Callovian-Oxfordian. The reservoir of reef-bank facies was well developed in the period of transgression, while the regional dense cap rocks developed in the period of regression; 2) $\mathrm{The}{ }^{87} \mathrm{Sr} /{ }^{86} \mathrm{Sr}$ ratio measured from rudist shells yields an age of $157.2 \mathrm{Ma}$ according to the global strontium isotope curve; 3) As diagenetic intensity increased, $\delta^{13} \mathrm{C}$ changed little, and $\delta^{18} \mathrm{O}$ showed strong negative deviation but was still limited to the range of Late Jurassic seawater. High $\mathrm{Fe}$ and $\mathrm{Sr}$ contents, and low Mn content, and the evolutionary trend of $\delta^{13} \mathrm{C}$ and $\delta^{18} \mathrm{O}$ all indicate that diagenesis occurred in a relatively confined environment, where the fluids were relatively reducing and contained hot brine. The stage of diagenesis reached is mesodiagenesis, which is very favorable for preservation of primary pores in carbonates; 4) Strong dissolution of reef limestones, burial dolomitization and hydrothermal calcite precipitation were all the results of the interaction between the ${ }^{87} \mathrm{Sr}$-rich diagenetic fluid and rocks; 5) The analysis results of isotopes, fluid inclusions and vitrinite reflectance show that the diagenetic fluid was compaction-released water that originated from the deep, coal-bearing clastic strata.
\end{abstract}

Key words: Trace element ( $\mathrm{Fe}, \mathrm{Sr}, \mathrm{Mn})$, carbon, oxygen, strontium stable isotopes, diagenetic fluid, Callovian-Oxfordian, Samandepe gas field, Turkmenistan

\section{Introduction}

Geochemical methods dealing with trace elements and stable isotopes (carbon, oxygen and strontium) in marine carbonates are widely used to study the change of global sea level, and paleoenvironment, diagenetic evolution and fluid properties of these rocks (Emrich et al, 1970; Veizer and Hoefs, 1976; Scholle and Arthur, 1980). Veizer et al (1986) established the carbon and oxygen isotope curves that could reflect the global sea-level change from Paleozoic to Mesozoic; McArthur et al (2001) created a strontium isotope curve that can be used to calibrate the stratigraphic age; Green and Mountjoy (2005) studied the origin of Devonian and Mississippi dolomite reservoirs in Western Canada Basin by using strontium isotopes; Swart et al (2005) investigated

* Corresponding author. email: zhengrc@cdut.edu.cn

Received September 19, 2010 the origin of Jurassic-Cretaceous dolomite reservoirs in the Arabian Gulf region. Based on the analysis of different corrosive intensities and textural constituents, trace elements, and carbon, oxygen and strontium stable isotopes of cements in karst rocks, the fluid properties, sources, and evolution of paleokarst reservoirs were analyzed, and the diagenetic fluid systems were distinguished in upper Carboniferous Huanglong Formation, eastern Sichuan area (Zheng et al, 1997; 2008b; 2009; Hu et al, 2008). With carbon, oxygen, strontium stable isotopes, the origin of dolomite reservoirs and the relationship between their origin and hydrocarbon accumulation were studied in the Upper Permian Changxing Formation and Lower Triassic Feixianguan Formation, northeastern Sichuan (Zheng and Shi, 2008; Zheng et al, 2007; 2008a; Shi et al, 2009). By analyzing carbon and oxygen isotopes, Li et al (2007) and Liu et al (2007) separately investigated the sequence stratigraphy of Triassic carbonates in southwestern Guizhou and upper Jurassic 
carbonates in Qiangtang basin. By using carbon and oxygen isotopes, Yao et al (2009) discussed the genesis of Lower Ordovician Majiagou Formation dolostone in Ordos basin. Zeng et al (2010) discussed the origin of paleofluids in Dabashan foreland thrust belt by using geochemical evidences of ${ }^{13} \mathrm{C},{ }^{18} \mathrm{O}$ and ${ }^{87} \mathrm{Sr} r{ }^{86} \mathrm{Sr}$ of veins and host rocks. Zhang et al (2009) studied the high-resolution records of the Holocene paleoenvironmental variation and response to glacial activities by carbonate and its isotopic compositions in Bosten Lake. Jiao et al (2010) applied trace elements in the study of oil-source correlation and hydrocarbon migration in the Tarim Basin, China. The Samandepe gas field in the contract area of China Petroleum on the right bank of Amu Darya (Turkmenistan) is a superlarge natural gas pool, which has been exploited since the former Soviet Union. The gasbearing beds are Callovian-Oxfordian carbonates of shallow

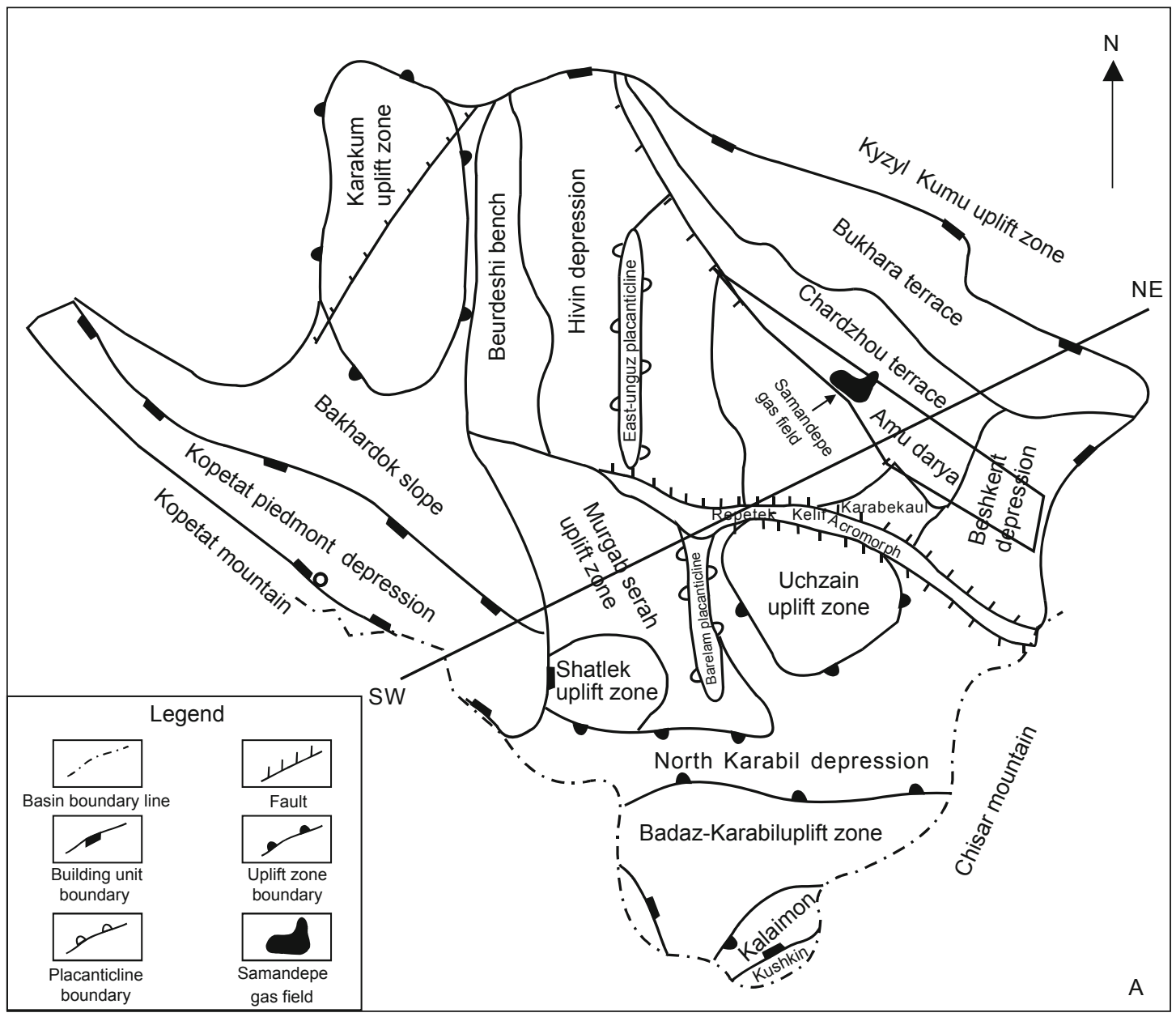

Southwest

Noutheast

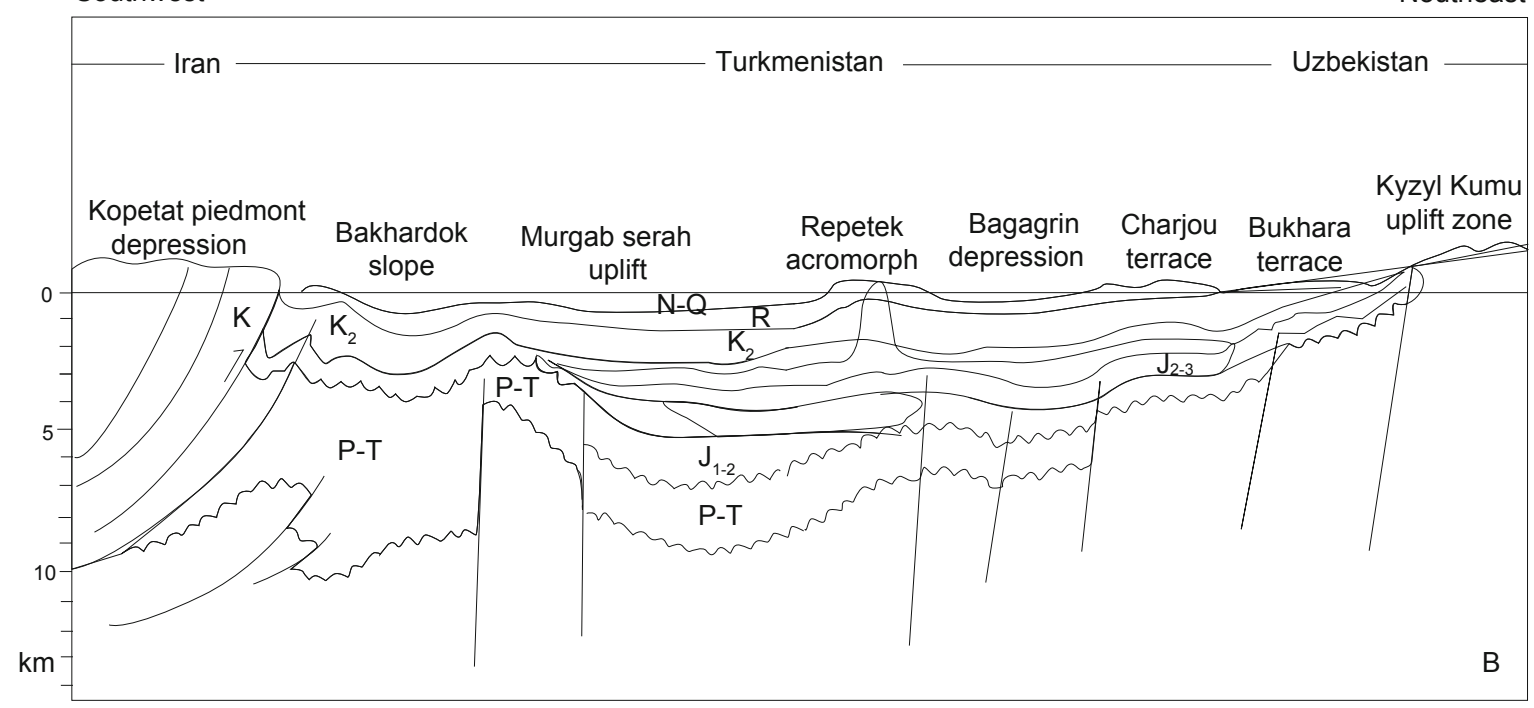

Fig. 1 Regional structural map of the Amu darya right bank area (Thomas et al, 1995) 
platform facies. It has a very good combined configuration relationship of source-reservoir-cap rock assemblage, and excellent lower source-middle reservoir-upper cap rock closed trapping accumulation conditions. However, in the former Soviet Union, particular attention was paid to the development of natural gas, hence the basic geologic data are deficient. Therefore, the research of trace element and carbon, oxygen and strontium stable isotopes are useful to reveal information about the deposition, diagenesis, and reservoir evolution of the Callovian-Oxfordian carbonates. It can offer an example of, and provide the basis for, improving the accuracy of reservoir evaluation, and development efficiency in gas fields on the right bank of Amu Darya.

\section{Geological setting}

\subsection{Tectonic framework}

Amu Darya basin is a large hydrocarbon-rich depositional basin in southeastern Tulan platform (Meisel et al, 1995) (Fig. 1A). The basin is lithologically and structurally divided into three layers, including basement, intermediate layer, and platform cover (Fig. 1B). The basement consists of Paleozoic igneous and metamorphic rocks, at different burial depths. The shallowest Karakum terrace is less than 2,000 $\mathrm{m}$ deep. The deepest, northern, Karabil depression is more than 14,000 $\mathrm{m}$ deep. The intermediate layer is composed of Permian-Triassic, terrigenous, coal-bearing clastic rocks with great variation in thickness: the northern part is thicker than the southern part. The maximum thickness of the Kopet piedmont depression in the southern basin is about $12,000 \mathrm{~m}$. The platform cover is composed of carbonates, evaporites, sandstones, mudstones, and coal beds of Jurassic, Cretaceous, and Paleogene age. Two groups of northwest- and northeaststriking faults controlled the structural framework and the distribution of sedimentary cover. Based on the morphology of the basement and structure, the Amu Darya basin is divided into a number of large structural units, including Kopetat piedmont depression, central Karakym uplift, Murgab SerahBagagrin depression and Charjou terrace. Samandepe gas field is located in the marginal zone of the southwestern Charjou terrace, which is adjacent to the Bagagrin depression (Fig. 1A).

\subsection{Stratigraphic background of Jurassic}

The Jurassic, Cretaceous and Paleogene lithological make-up of the Amu Darya basin is complex. It includes coal-bearing clastic rocks of coastal plain to lagoonal swamp facies, migmatite of shallow continental shelf facies, carbonates of open-restricted platform facies, and gypsumsalt rocks of evaporated platform facies. The Middle-Upper Jurassic Callovian-Oxfordian strata are the most important gas producing horizons in the Samandepe gas field. These strata have a discordant overlapping contact relationship with underlying Middle Jurassic coal-bearing clastic rocks of lagoon to swamp facies, and a continuous depositional relationship with overlying thickly layered gypsum-salt rock of the Upper Jurassic, Kimmeridgian, Gordak Formation. The reservoir is composed of a carbonate complex association including foreslope, reef and bank at the platform margin, carbonate and gypsum-salt of evaporated platform facies. From bottom to top, the carbonate reservoirs can be subdivided into seven lithologic units: the lower reef (XVa1), dense layer $(Z)$, reef layer (XVa2), upper reef (XVhp), massive limestone $(\mathrm{XVm})$, laminated limestone $(\mathrm{XVp})$, and limestone-gypsum layer (XVac) (Fig. 2). The underlying Middle Jurassic coal-bearing strata are the chief source rocks in the Samandepe gas field, and the reservoir of the gas field mainly developed in Oxfordian XVa2, XVhp, XVm and XVp layers. The overlying limestones and gypsums, together with thickly layered gypsum-salt in the Gordak Formation are dense, regional cap rocks. Therefore, the reef layer (XVa2) of the Samandepe gas field has an excellent source-reservoircap rock configuration, as well as lower source-middle reservoir-upper cap rock trapping conditions.

\section{Types and features of samples}

The samples used in our work were obtained from well Sam53-1. Samples were collected according to textural genetic classification (Zeng and Xia, 1986), and were identified by microscope to ensure that they are representative of the range of rocks present. The samples are divided into three types, namely limestone, dolostone and calcite crystal. The limestones are mainly micrite, grain limestones, and reef limestones, and dolostones are mainly limey, silty, crystalline dolostones and silty to finely crystalline dolostones.

\subsection{Micrite}

The micrites are composed of micritic to cryptocrystalline calcites, and formed in a low-energy environment, such as a subtidal zone of restricted and open platform, and front ramp. The rock is dense with only partial dissolution pores and dissolution fractures developed locally. Except for fracture zones, it is generally unfavorable for reservoir development.

\subsection{Grainstones}

The grainstones are mainly composite grainstones, and can be subdivided into microsparry bioclastic limestone, arenaceous bioclastic limestone, rudaceous bioclastic limestone, ooid limestone, oncolitic limestone and bioclastic pelleted limestone. The bioclastic limestone is the richest, and its bioclastic constituents are mainly rudistids, corals, bryozoan, foraminifera, brachiopods, echinoderms, as well as red, green, and blue-green algae, and a minor component of cephalopods, spiculae, and calcispheres. Some bioclasts are converted into silicate and gypsum. At their maximum, these rocks were subjected to low to moderate diagenetic processes, including cementation, compaction, dissolution, recrystallization and local dolomitization. The void spaces are primary intergranular pores, residual primary intergranular pores, intergranular and intragranular dissolved pores and fissures (Fig. 3B-E), and the primary intergranular pores are the largest. The grainstones have a porosity of $6 \%-16 \%$, with an average value of about $10 \%$, and its permeability is 0.01 to $423.8 \times 10^{-3} \mu^{2}$, with an average value of $16.13 \times 10^{-3} \mu \mathrm{m}^{2}$. The grainstone is one of the important reservoir types in the Samandepe gas field. 


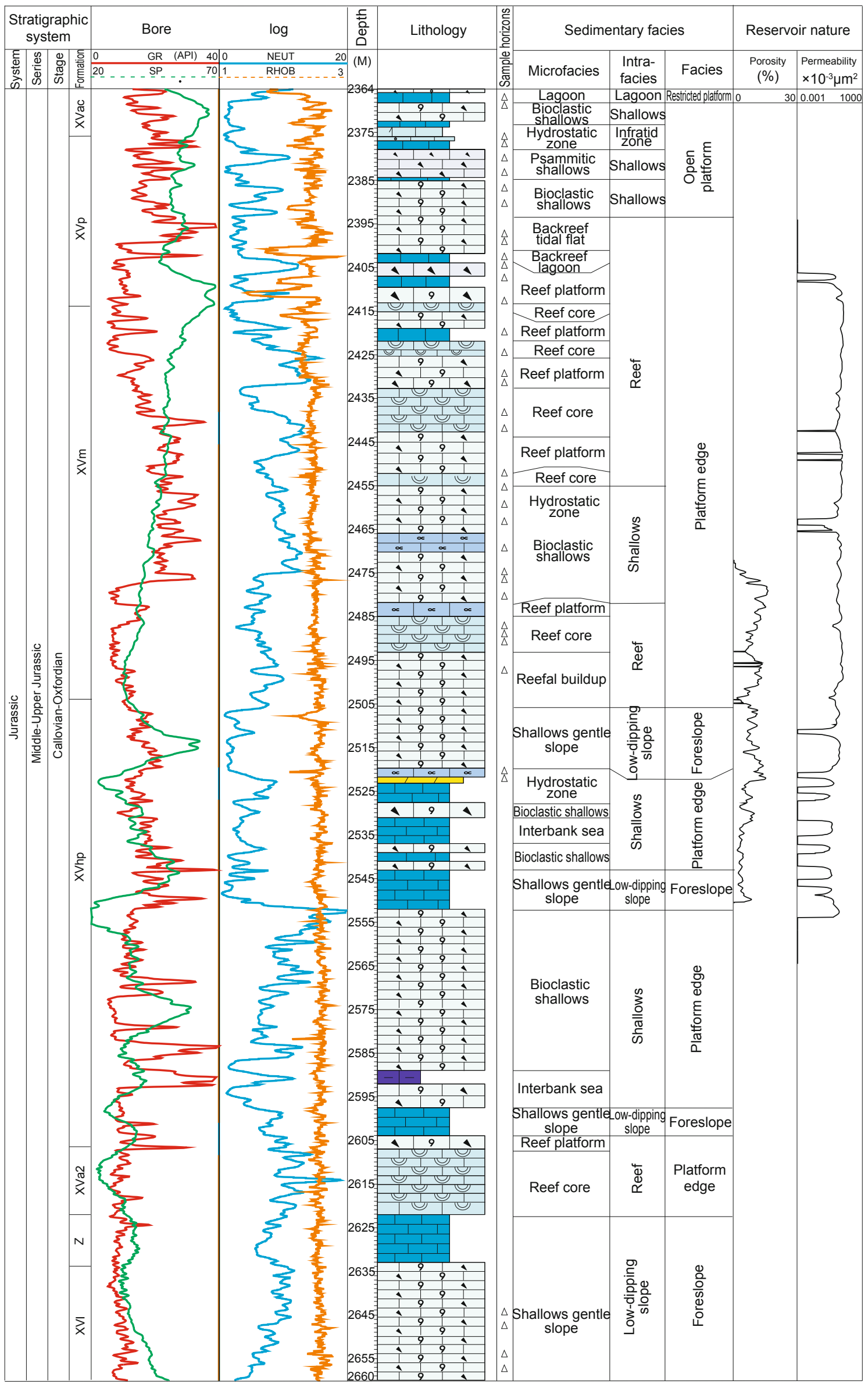

Fig. 2 Comprehensive column of Callovian-Oxfordian sedimentary facies and reservoir characteristics in Amu Darya basin (from well Sam53-1) 


\subsection{Reef limestones}

The reef limestones are developed in layers $\mathrm{XVm}$ and $\mathrm{XVa}$ 2. The frame builders are mainly rudistids and corals - of which rudistids, at greater than $50 \%$, is the largest part - followed by corals, red algae, bryozoan and sponge. Stromatoporoids are locally observed. The micritization of frame builders is intense, and dissolution of skeletonal and coelomic cavities is very common. The framestones and bindstone dominated by rudistids and corals have strong wave resistance in high energy water. Intergranular frameworks are partly cemented by calcsparite, and filled with bioclastics and lime mud which are formed by wave-cut abrasion. The solution process during the diagenetic stage is intensive, and the dissolved pores and fissures are strongly developed (Fig. $3 \mathrm{~F}-\mathrm{G})$. The porosity of the reef limestones is $6.0 \%-28.6 \%$, with an average value of $16 \%$, and the permeability is between $0.06 \times 10^{-3} \mu^{2}$ and $3155.3 \times 10^{-3} \mu^{2}$, with an average value of $306.9 \times 10^{-3} \mu \mathrm{m}^{2}$. Hence, this type of rock is favorable for the development of a reservoir.
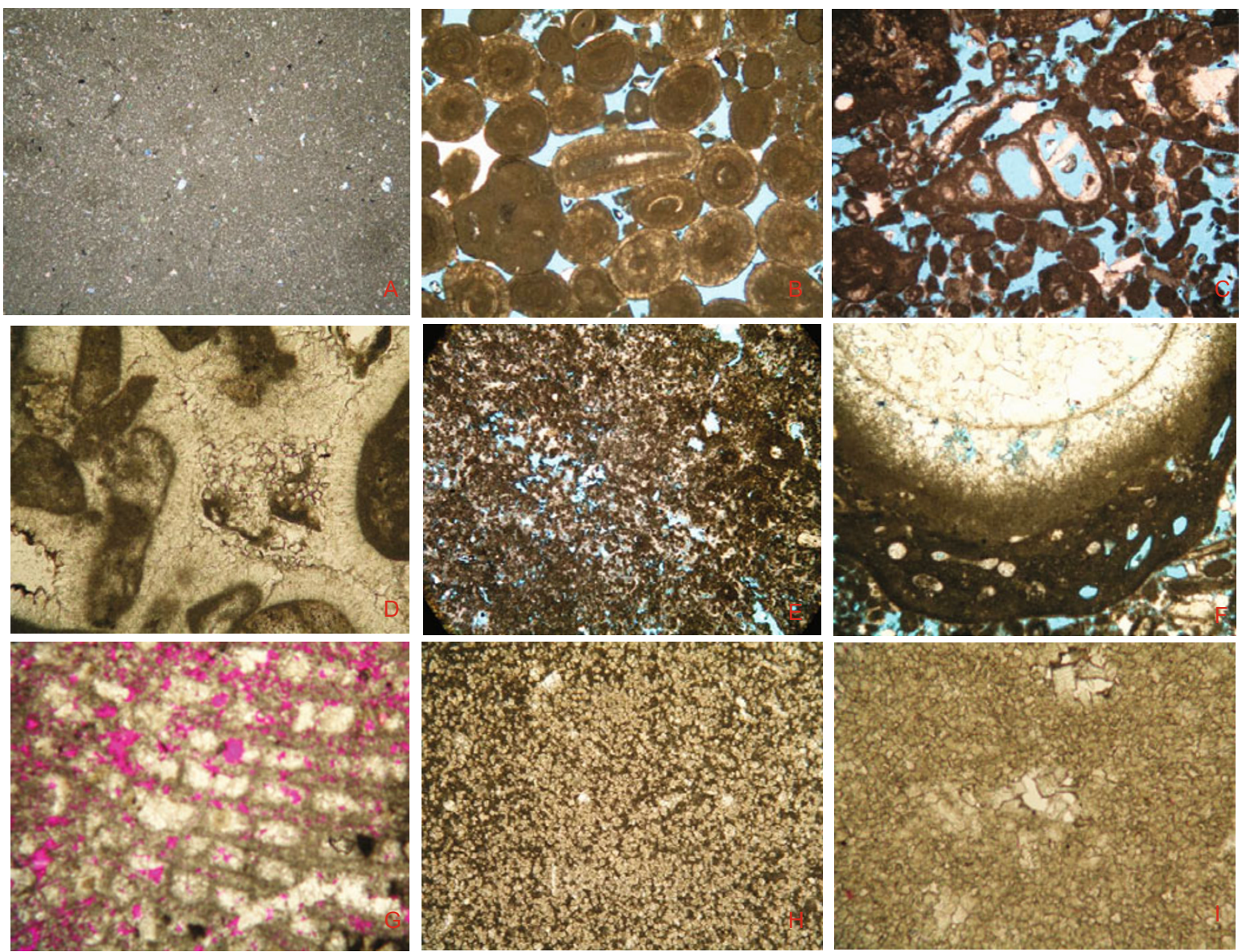

Fig. 3 Various types of Callovian-Oxfordian carbonate reservoirs in Samandepe gas field (from borehole of well Sam53-1)

(A) Micrite, layer XVp, $2407.53 \mathrm{~m}$. Plane polarized light image of thin section of blue-impregnated sample. Diagonal length $4.6 \mathrm{~mm}$. (B) Ooid sparite, primary intergranular pores, layer XVac, $2372.69 \mathrm{~m}$. Plane polarized light image of thin section of blue-impregnated sample. Diagonal length $4 \mathrm{~mm}$. (C) Micro-sparitic bioclastic limestone. Bioclasts are mainly rudists, foraminiferas, echinoderms, brachiopods and green algae. The bioclastics are micritized, with a little granular calcsparitic cement, irregularly distributed. Residual primary intergranular pores, and intergranular and intragranular dissolved pores, are very well developed. Layer XVm, $2454.76 \mathrm{~m}$. Plane polarized light image of thin section of blue-impregnated sample. Diagonal length $4 \mathrm{~mm}$. (D) Bioclastic sparite, with cements of two generations, layer XVhp, $2517.75 \mathrm{~m}$. Plane polarized light image of normal thin section. Diagonal length $4 \mathrm{~mm}$. (E) Algal limestone composed of dark-colored patchy algae, layer XVm, $2476.61 \mathrm{~m}$. Plane polarized light image of thin section of blueimpregnated sample. Diagonal length 4mm. (F) Micro-sparitic rudist reef limestone. The rudists coelom is composed of calcsparite, of which parts are dissolved, layer XVm, $2454.76 \mathrm{~m}$. Plane polarized light image of thin section of blue-impregnated sample. Diagonal length $4.6 \mathrm{~mm}$. (G) Coral reef limestones, parts of coral coelom are dissolved, layer XVm, 2460.05 m. Plane polarized light image of thin section of red-impregnated sample. Diagonal length $4.6 \mathrm{~mm}$. (H) Limey, micro-silt, crystalline dolostone with bioclasts of: echinoderms, spicules and bryozoan, layer XVa2, $2659.25 \mathrm{~m}$. Plane polarized light image of thin section of blue-impregnated sample. Diagonal length $4.6 \mathrm{~mm}$. (I) Silty crystalline dolostone replaced by celestine, intercrystal pores, layer XVac, $2372.52 \mathrm{~m}$. Plane polarized light image of thin section of blue-impregnated sample. Diagonal length $1.8 \mathrm{~mm}$

\subsection{Limey, silty crystalline dolostone}

This type of limey, silty crystalline dolostone is developed in layer XVhp, and is partially converted into silicate and anhydrite. The main rock types are residual bioclastic spicule limey dolostone, residual bioclastic limey dolostone, and limey, silty crystalline dolostone (Fig. 3H), which are 
partially replaced by silicate, and silty, finely crystalline limey dolostone which is partially repalced by silicate and anhydrite. Because the silicification, anhydrite replacement, and dolomitization are uneven and incomplete, porphyritic residual lime mud can be seen in the rock, or micritic calcite be seen between dolomite crystals. The porosity of this type rock is less than $4 \%$, and the permeability is less than $1 \times 10^{-3}$ $\mu \mathrm{m}^{2}$. The lithology of this type rock is unfavorable for the development of a reservoir.

\subsection{Crystalline dolostones}

Crystalline dolostones are developed in layers XVhp and XVa2, and are characterized by crystalline granular texture with high degree of dolomitization. The lithology is dominated by silty, finely crystalline dolostone, and composed of subhedral to euhedral dolomite crystals, whose crystal size varies from 0.03 to $0.15 \mathrm{~mm}$. The rock is mostly massive, with widespread development of intercrystalline pores and intercrystalline dissolved pores. Residual bioclastic texture, anhydrite replacement and celestite replacement are locally observed (Fig. 3I). The porosity of this type rock is $4.0 \%$ to $10 \%$, with an average value of $6 \%$, and the permeability is between $0.06 \times 10^{-3} \mu \mathrm{m}^{2}$ and $22.6 \times 10^{-3} \mu \mathrm{m}^{2}$, with an average value of $12 \times 10^{-3} \mu^{2}$. The lithology of this rock is favorable for reservoir development, but due to its small thickness and narrow distribution, the potential of gas accumulation is rather limited.

\section{Geochemical behaviors of Callovian- Oxfordian carbonates}

\subsection{Characteristics of $\mathrm{Fe}, \mathrm{Mn}$, and $\mathrm{Sr}$ trace elements}

\subsubsection{Fundamental principle}

Trace element analysis has extensive application in geotectonics, stratigraphy, paleontology, economic geology, environmental geology and petroleum geology. Actions, such as the conversion of aragonite or magnesian calcite into calcite, and dolomitization and dedolomitization during diagenesis, are accompanied by the trace element redistribution and balance between intergranular water and carbonate minerals in water-rock reaction (Emrich et al, 1970; Veizer and Hoefs, 1976; Scholle and Arthur, 1980). Therefore, trace elements ( $\mathrm{Fe}, \mathrm{Mn}$, and $\mathrm{Sr}$ ) can provide more information than major elements $(\mathrm{Ca}, \mathrm{Mg})$ in the interpretation of carbonate origin.

\subsubsection{Sample distribution and geologic interpretation}

The ranges and averages of analyses for Fe, $\mathrm{Mn}$, and $\mathrm{Sr}$ trace elements of 49 samples are shown in Table 1, and their explanations are as follows:

Table 1 Distribution of $\mathrm{Fe}, \mathrm{Mn}$ and $\mathrm{Sr}$ trace elements in Callovian-Oxfordian carbonates

\begin{tabular}{|c|c|c|c|c|c|c|c|}
\hline \multirow{2}{*}{$\begin{array}{l}\text { Distribution of } \\
\text { carbonates }\end{array}$} & \multirow{2}{*}{$\begin{array}{c}\text { Number of } \\
\text { samples }\end{array}$} & \multicolumn{2}{|c|}{$\mathrm{Fe}^{2+}, \%$} & \multicolumn{2}{|c|}{$\mathrm{Mn}^{2+}, \%$} & \multicolumn{2}{|c|}{$\mathrm{Sr}^{2+}, \%$} \\
\hline & & Range & Average & Range & Average & Range & Average \\
\hline Micrite & 13 & $0.046-2$ & 0.513 & $0.0018-0.024$ & 0.00492 & $0.019-0.048$ & 0.0297 \\
\hline Grainstones & 14 & $0.0097-0.067$ & 0.0393 & $0.0016-0.0043$ & 0.00257 & $0.018-0.062$ & 0.0246 \\
\hline Reef limestone & 8 & $0.016-0.073$ & 0.0389 & $0.0017-0.0036$ & 0.00245 & $0.013-0.03$ & 0.0206 \\
\hline Limey dolostone & 7 & $0.082-0.28$ & 0.162 & $0.0023-0.016$ & 0.0076 & $0.017-0.046$ & 0.0239 \\
\hline $\begin{array}{l}\text { Crystalline } \\
\text { dolostone }\end{array}$ & 2 & $0.091-0.23$ & 0.161 & $0.0052-0.0084$ & 0.0068 & $0.012-0.014$ & 0.013 \\
\hline Calcite crystal & 5 & $0.017-0.041$ & 0.0286 & $0.0015-0.0036$ & 0.00292 & $0.015-0.05$ & 0.0276 \\
\hline
\end{tabular}

Notes: The analysis results are provided by the Analysis center under Chengdu Institute of Multipurpose Utilization of Mineral Resources, Chinese Academy of Geological Science; Test instrument: ICP-AES 5300V (Thermo Electron Corporation, USA); Test standard: Y/T05$1996<$ ICP broadspectrum $>$; Analytical error: $\pm 0.0005 \%$

1) The content and range of Fe, Mn, and Sr trace elements from different samples are similar: very high content of Fe, high content of $\mathrm{Sr}$, and low content of $\mathrm{Mn}$. In general, the diagenetic fluids have strong reductive properties, and lack the influence of continental fresh water (Kaufman et al, 1992).

2) Trace element contents (Fe, Mn and Sr) of different samples have their own patterns, which reflect the evolution of trace element distribution during diagenesis: (1) Micrite had poor porosity and permeability, and experienced weak alteration during burial. The distribution of trace elements is very similar to that of the original sediment. (2) Grainstones and reef limestones had good porosity and permeability, and experienced strong alteration during burial. Compared with micrite, Fe and Mn were strongly diluted, and Sr changed slightly. It appears that both limestones were altered under the influence of low Fe and Mn fluids sourced from the strata themselves. (3) With increasing dolomitization, Sr content decreased, while Fe and $\mathrm{Mn}$ contents increased slightly, which is associated with a low $\mathrm{Sr}^{2+}$ partition coefficient in dolomite (much less than 1), and with an increase of $\mathrm{Mg}^{2+} /$ $\mathrm{Ca}^{2+}$ ratio due to replacement of $\mathrm{Ca}^{2+}$ by $\mathrm{Mg}^{2+}$ in the fluid. Simultaneously, $\mathrm{Fe}^{2+}$ and $\mathrm{Mn}^{2+}$, with smaller ionic radius, were relatively concentrated, and $\mathrm{Sr}^{2+}$, with larger ionic radius, was leached. It also demonstrates that the diagenetic fluid originated from strata which had high temperature and were strongly reducing (Huang et al, 2006). (4) Fe, Mn and $\mathrm{Sr}$ content of calcite crystals, which resulted from the precipitation out of hydrothermal fluid, infilling cavities and fractures (i.e. hydrothermal calcite crystals), is close to that of grainstones and reef limestones, indicating that the sources of calcite crystals were mainly from these two kinds of 
limestones, which were dissolved by the hydrothermal fluid.

3) Fig. 4 shows $\mathrm{Fe}, \mathrm{Mn}$ and $\mathrm{Sr}$ contents versus burial depth. It can be seen that samples from shallower than 2,430 $\mathrm{m}$ are more scattered, whereas samples from below 2,430 m tend to cluster with increasing depth. Fe and Mn contents, and $\mathrm{Mn} / \mathrm{Sr}$ ratio, show poor positive correlation with depth, and the correlation coefficients ( $R$ values) are, respectively,
$0.0641,0.0916$ and 0.2724 . In particular, the $\mathrm{Mn} / \mathrm{Sr}$ ratio exhibits a more significantly positive correlation with the depth. Only Sr content shows obviously negative correlation with the depth, with an $R$ value of -0.2751 . This reflects that, besides temperature, enhanced reducing conditions and homogenization of diagenetic fluid, with increasing burial depth, are also important affecting factors on the diagenesis.
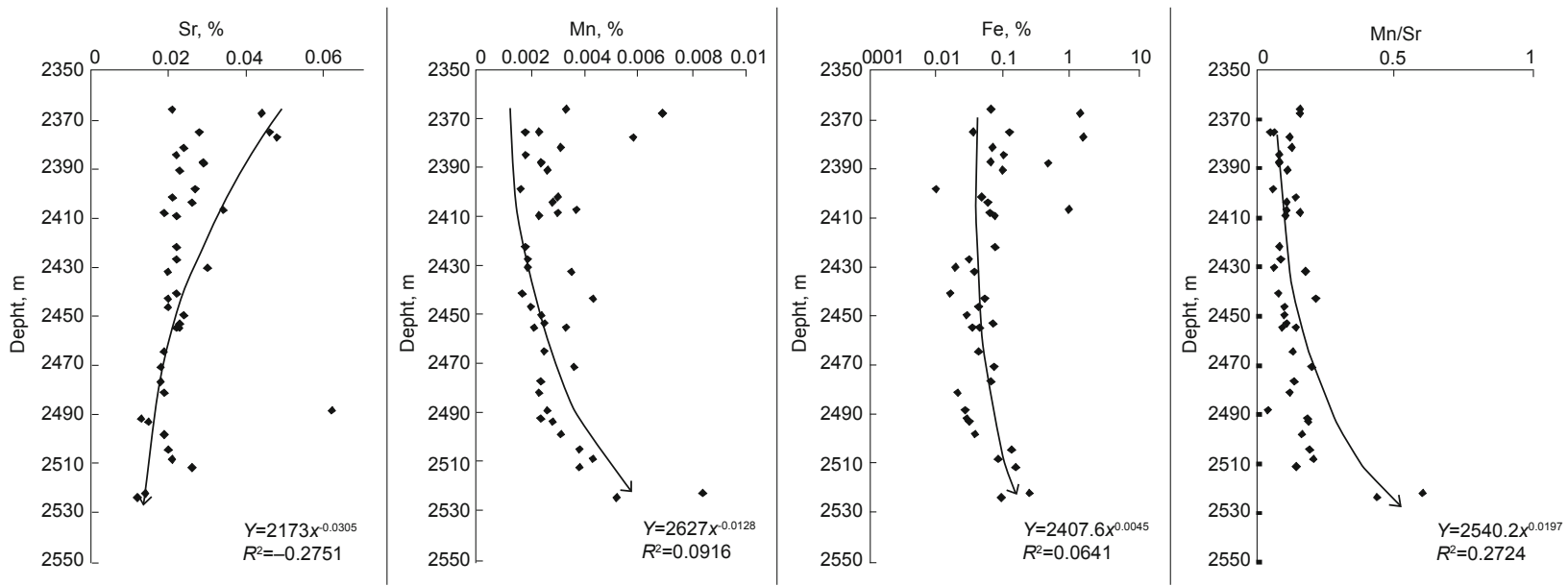

Fig.4 Plots showing the changes of $\mathrm{Sr}, \mathrm{Mn}, \mathrm{Fe}$ content and $\mathrm{Mn} / \mathrm{Sr}$ versus the burial depth

\subsection{Characteristics of $\mathrm{C}$ and $\mathrm{O}$ isotopes}

\subsubsection{Fundamental principle}

The abundance of ${ }^{13} \mathrm{C}$ and ${ }^{18} \mathrm{O}$ in marine carbonates is mainly affected by transgression-regression cycles, source and burial rate of organic carbon, and oxidation-reduction conditions of the depositional and diagenetic environment (Veizer et al, 1986). Ordinarily, with increasing burial rate of organic carbon, $\delta^{13} \mathrm{C}$ will be heavier in the background of transgression and shows positive shift, otherwise the $\delta^{13} \mathrm{C}$ tends to be lighter and shows negative shift. The carbonate has a trend towards low ${ }^{13} \mathrm{C}$ and high ${ }^{12} \mathrm{C}$ under oxidizing conditions, and ${ }^{18} \mathrm{O}$ is more strongly affected by temperature and salinity of the medium under alkaline reducing conditions. In an equilibrium diagenetic system, the migration of solid $\delta^{13} \mathrm{C}$ needs pore solution at least 1500 times of their own volume, and the same change for $\delta^{18} \mathrm{O}$ needs a pore solution only 5 times more than their own volume (Li and Liu, 1996). This indicates that the effect of diagenesis is larger on $\delta^{18} \mathrm{O}$ than on $\delta^{13} \mathrm{C}$. During diagenesis of carbonate sediments, the less stable minerals such as aragonite, magnesian calcite and proto-dolostone will experience mineral phase transition, and recrystallization, replacement and deposition of carbonate cement. All of these will change the carbon and oxygen components of the original sediment. Therefore, differing depositional-diagenetic environments result in different compositions, and these variations can help to identify the depositional-diagenetic environment and the properties of diagenetic fluid.

\subsubsection{Sample distribution and geologic interpretation}

The ranges and averages of analyses of $\mathrm{C}$ and $\mathrm{O}$ isotopes of 51 samples are shown in Table 2, and their interpretations are as follows:

Table 2 Distribution of $\mathrm{C}$ and $\mathrm{O}$ isotopes of Callovian-Oxfordian carbonates

\begin{tabular}{|c|c|c|c|c|c|c|c|}
\hline \multirow{2}{*}{$\begin{array}{l}\text { Distribution of } \\
\text { carbonates }\end{array}$} & \multirow{2}{*}{$\begin{array}{c}\text { Number of } \\
\text { samples }\end{array}$} & \multicolumn{2}{|c|}{$\delta^{13} \mathrm{C}_{\mathrm{PDB}}, \% 0$} & \multicolumn{2}{|c|}{$\delta^{18} \mathrm{O}_{\mathrm{PDB}}, \%$} & \multicolumn{2}{|c|}{$Z$} \\
\hline & & Range & Average & Range & Average & Range & Average \\
\hline Micrite & 15 & $2.76-5.32$ & 4.33 & $-5.24-0.06$ & -1.5 & $131.1-138.1$ & 135.4 \\
\hline Grainstones & 14 & $3.76-5.98$ & 4.27 & $-2.58-0.3$ & -1.58 & $134-139.7$ & 135.2 \\
\hline Reef limestone & 8 & $3.78-4.42$ & 4.04 & $-2.7--0.89$ & -1.90 & $133.8-135.9$ & 134.6 \\
\hline Limy dolostone & 7 & $3.31-4.51$ & 3.95 & $-4.89--0.53$ & -2.82 & $131.9-135.9$ & 134 \\
\hline $\begin{array}{c}\text { Crystalline } \\
\text { dolostone }\end{array}$ & 2 & $4.82-4.92$ & 4.87 & $-4.49--4.37$ & -4.43 & $134.9-135.2$ & 135.1 \\
\hline Calcite crystal & 5 & $3.75-4.24$ & 4.04 & $-5.46--0.91$ & -4.07 & $132.7-135.5$ & 133.5 \\
\hline
\end{tabular}

Notes: The analysis result are provided by Geological laboratory of research institute of petroleum exploration and development, Southwest Oil and Gas Company of CNPC; Test instrument: MAT252 mass spectrometer (Finnigan MAT, USA); Test standard: SY/T 6039-94; Working standard: TTB-2; Analytical error: $\pm 0.005 \%$ 
1) Carbon and oxygen stable isotopic compositions of all the samples are in the distribution range of Late Jurassic marine carbonates, established by Veizer et al (1986). $\delta^{13} \mathrm{C}$ changes little and values are positive $(4.87 \% 0-3.95 \%)$, whereas the variation in $\delta^{18} \mathrm{O}$ is relatively high $(-1.5 \%$ to $-4.43 \%$ ) and the values are negative. According to the formula for Salinity Index ( $Z$ ) developed by Keith and Weber (1964) $[Z=2.048$ $\left.\left(\delta^{13} \mathrm{C}_{\mathrm{PDB}}+50\right)+0.498\left(\delta^{18} \mathrm{O}_{\mathrm{PDB}}+50\right)\right]$, the variation range of the calculated $Z$ value of all the samples is 131-135.4 (taking $Z=120$ as a boundary between seawater and fresh water, higher $Z$ values indicate higher fluid salinity), reflecting that diagenesis did not change the marine depositional characteristics of all the samples.

2) Based on Kaufman et al. (1992) that $\mathrm{Sr}>0.02 \%, \mathrm{Mn} /$ Sr ratios $<2$, and $\delta^{18} \mathrm{O}(\mathrm{PDB})>-5 \%$ ore criteria indicating preservation of original seawater information of samples, except dolomite and hydrothermal calcite samples, it can be determined that 32 of the 37 limestone samples did not suffer, or suffered only weak, diagenetic alteration. For the sample from the outer shell of rudistids, which did not suffer diagenetic alteration, the $\mathrm{Sr}$ content is $0.024 \%, \mathrm{Mn} / \mathrm{Sr}$ ratio is $0.1, \delta^{18} \mathrm{O}$ is $-1.97 \%$, and the ${ }^{87} \mathrm{Sr} /{ }^{86} \mathrm{~S}$ ratio is 0.706812 , consistent with $\mathrm{Sr}$ isotope composition of coeval seawater by Price and Gröcke (2002), so this sample preserved the original seawater information well. In the relationship of $\delta^{13} \mathrm{C}$ versus $\delta^{18} \mathrm{O}$ (Fig. 5), 32 samples are relatively concentrated, but their correlations are poor, so the results may represent the carbon and oxygen isotope composition of original seawater. The analysis of Callovian-Oxfordian sea-level changes show the following characteristics (Fig. 6): (1) Sustained transgressive-regressive cycles played an important role during the Callovian-Oxfordian. Sea-level fell slowly and steadily from layer XVhp to the bottom of XVm, rose constantly and slowly from the bottom to the top of $\mathrm{XVm}$, and then rose rapidly in $X V p$, then finally changed to fall rapidly in XVac. The sea-level changes based on the carbon and oxygen isotopic compositions are consistent with the results of sedimentary facies analysis, and are also consistent with the global sea-level changes proposed by Veizer at al (1999). (2) Carbon and oxygen isotope composition during the sea-level rising stage are significantly controlled by sealevel change. The $\delta^{13} \mathrm{C}$ and $\delta^{18} \mathrm{O}$ curve of the XVhp and XVm, from falling to slow steady rising sea-level, fits well with the trend of global sea-level change (Veizer at al,1999). This reflects that the depositional environment was steady and laid a foundation for the development of the reef-bank reservoirs. (3) The sea-level falling phase corresponded to the global sealevel changing from accelerated rising to a rapid decline; the $\delta^{13} \mathrm{C}$ and $\delta^{18} \mathrm{O}$ curves of XVp and XVac are complicated and changeable, with a moderately high finger-shaped amplitude, but the trend has a good fitting relationship, indicating large sea-level fluctuation and unstable depositional environment.

3) In the relationship of $\delta^{13} \mathrm{C}$ versus $\delta^{18} \mathrm{O}$ for all the 51 samples, including samples that experienced no, or only weak, diagenetic alteration, and the direct products of diagenetic alteration, $\delta^{13} \mathrm{C}$ distribution is relatively stable (Fig. 5). However, with increasing diagenetic intensity, $\delta^{18} \mathrm{O}$ exhibits stronger negative deviation from limestones without

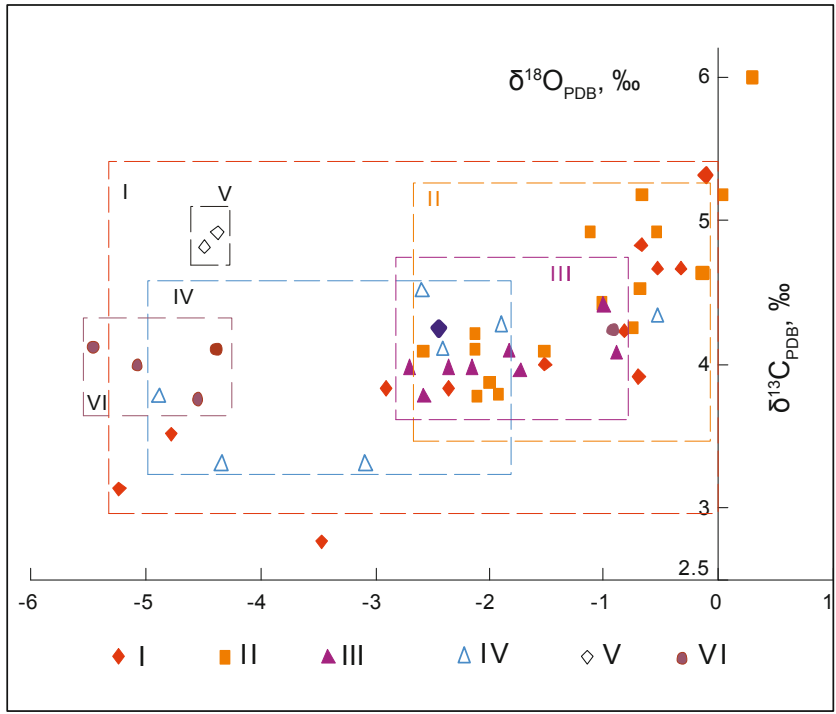

Fig. 5 Relationship of $\delta^{13} \mathrm{C}$ versus $\delta^{18} \mathrm{O}$ of different carbonates I. Micrite; II. Grainstone; III. Reef limestone; IV. Silty crystalline limey dolostone; V.crystalline dolostone. VI. Calcite crystal

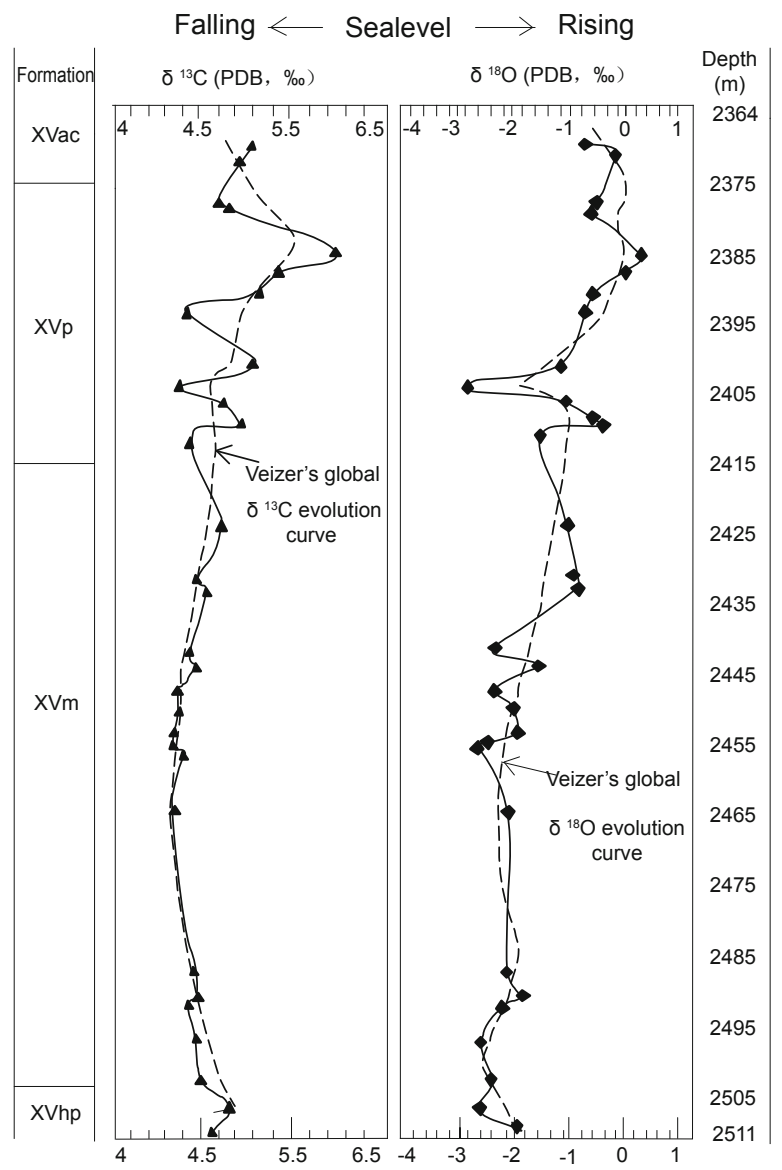

Fig. 6 Sedimentary evolution and the carbon, oxygen isotope curve of

Upper Jurassic in Amu Darya basin (from borehole of well Sam53-1)

diagenetic alteration, through limestones that underwent weak diagenetic alteration, to limey silty crystalline dolostone, crystalline dolostone, and hydrothermal calcite crystals, but its variation range is still limited to the distribution of Late Jurassic carbonates (Veizer et al, 1986). The calculated Z values reflect that the diagenetic fluid has high salinity. All 
these demonstrate that diagenesis took place in a relatively closed environment, and that the diagenetic fluids are mainly pore water from the sediments themselves and deep strata, and lacked any freshwater influence.

\subsection{Characteristics of strontium isotopes}

\subsubsection{Fundamental principle}

The strontium isotope composition of seawater in geological history is a function of time, and is mainly affected by two main sources of strontium (Spooner, 1976):

-Radioactive strontium from chemical weathering of ancient continental silicon aluminum rocks, with a high ${ }^{87} \mathrm{Sr} /{ }^{86} \mathrm{Sr}$ ratio, and a global average value of $0.719 ;$

-Minor radioactive strontium from hydrothermal systems of oceanic median ridge, with a low ${ }^{87} \mathrm{Sr} /{ }^{86} \mathrm{Sr}$ ratio, and a global average value of 0.7035 .

The ${ }^{87} \mathrm{Sr} /{ }^{86} \mathrm{Sr}$ ratio of seawater at different geologic times is the result of homogenization of different proportions of these two sources of strontium, and the time for homogeneous equilibrium is about one thousand years. Based on the principle that the mass difference of ${ }^{87} \mathrm{Sr}$ and ${ }^{86} \mathrm{Sr}$ is small, and that there is no strontium isotope fractionation, in either seawater or diagenetic fluid, when the carbonate minerals are deposited, the strontium isotopic composition obtained from fluid depends on the ${ }^{87} \mathrm{Sr} /{ }^{86} \mathrm{Sr}$ ratio of fluid. Therefore, the ${ }^{87} \mathrm{Sr} /{ }^{86} \mathrm{Sr}$ ratio preserved in carbonate minerals provides reliable geochemical information on the ${ }^{87} \mathrm{Sr} /{ }^{86} \mathrm{Sr}$ ratio of seawater at the time of carbonate deposition, the geologic period (strontium isotope stratigraphy), and the properties and sources of diagenetic fluids.

\subsubsection{Sample distribution and geological interpretation}

The ranges and averages of analyses of $\mathrm{Sr}$ isotopes of 45 samples are shown in Table 3, and their geological interpretation are as follows:

Table 3 Distribution of Sr isotopes of Callovian-Oxfordian carbonates

\begin{tabular}{|c|c|c|c|c|c|}
\hline \multirow[t]{2}{*}{ Sample } & \multirow{2}{*}{$\begin{array}{l}\text { Number } \\
\text { of } \\
\text { samples- }\end{array}$} & \multicolumn{2}{|l|}{${ }^{87} \mathrm{Sr} /{ }^{86} \mathrm{Sr}$} & \multicolumn{2}{|c|}{$\begin{array}{c}\text { Average value of } \\
\text { physical } \\
\text { properties }\end{array}$} \\
\hline & & Range & Average & $\varphi(\%)$ & $\mathrm{K}\left(\times 10^{-3} \mu \mathrm{m}^{2}\right)$ \\
\hline Rudistid shell & 1 & 0.706812 & & Null & Null \\
\hline Micrite & 11 & $0.70374-0.715369$ & 0.707933 & 2.2 & 0.15 \\
\hline Grainstones & 13 & $0.704625-0.710405$ & 0.706847 & 13.5 & 61 \\
\hline Reef limestone & 8 & $0.705839-0.718799$ & 0.708374 & 14.4 & 42.9 \\
\hline Limey dolostone & 6 & $0.704939-0.713959$ & 0.708328 & 4.5 & 0.36 \\
\hline Crystalline dolostone & 1 & 0.708747 & & 3.1 & 0.01 \\
\hline Calcite crystals & 5 & $0.706314-0.71187$ & 0.708558 & Null & Null \\
\hline
\end{tabular}

Notes: The analytical results are provided by isotopic element laboratory of Chengdu University of technology; Test instrument: MAT261 mass spectrometer (Finnigan-MAT, USA). International commonly-used sample dissolution is separated and purified by cation exchange column. Experimental condition: temperature $22{ }^{\circ} \mathrm{C}$, moisture $50 \%$; Examine criterion: Guide Sample NBS987 of the National Institute of Standards and Technology, USA; analytic error: $\pm 0.002 \%$.
1) Shells are not significantly altered by diagenesis and often contain information about the isotopic composition of coeval seawater. This can be used to calibrate the stratigraphic age (Derry et al, 1994). The ${ }^{87} \mathrm{Sr} /{ }^{86} \mathrm{Sr}$ ratio of rudistid shells used in this work is 0.706812 , corresponding to an age of 157.2 Ma (Fig. 7), according to the global strontium isotope curve (McArthur et al, 2001), consistent with the Callovian-Oxfordian age provided by the international chronostratigraphic table (164.7-155.7 Ma).

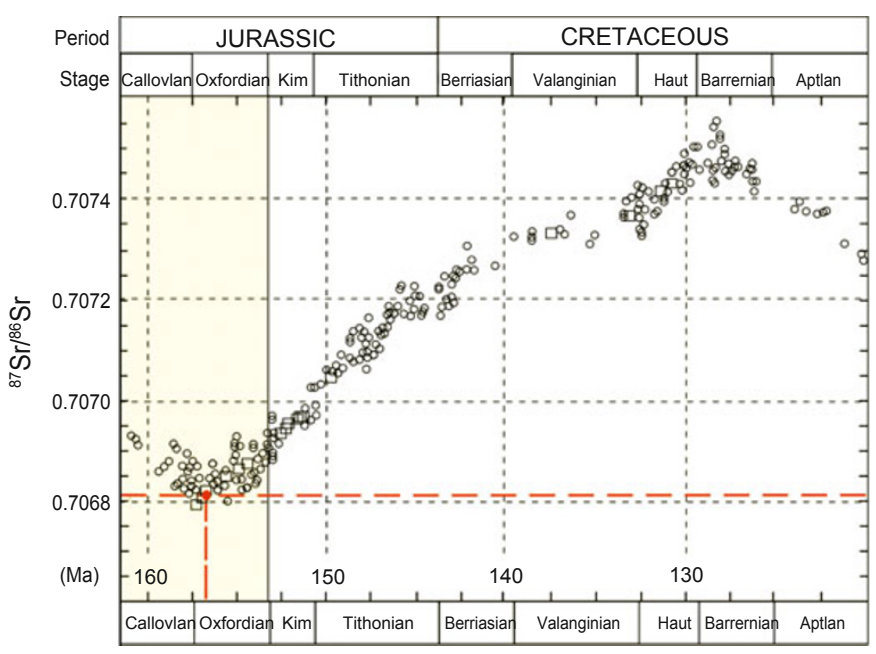

Fig. $7{ }^{87} \mathrm{Sr} /{ }^{86} \mathrm{Sr}$ ratio of rudistids shell in Jurassic-Cretaceous global isotope curve (after Price and Gröcke, 2002)

2) $\mathrm{The}{ }^{87} \mathrm{Sr} /{ }^{86} \mathrm{Sr}$ ratio of the micrite is in the range $0.703740-0.715369$, with an average value of 0.707933 , which is significantly higher than that of the global seawater (from 0.706789 to 0.706942 ) represented by rudistid shells. Considering that most micrite has well preserved carbon and oxygen isotopes of original seawater and the influence of diagenetic alteration on strontium isotope can be neglected, the reason for the high ${ }^{87} \mathrm{Sr} /{ }^{86} \mathrm{Sr}$ ratios of the micrite might be that micrite always contains more clay (the argillaceous content in microcrystalline limestone is $3 \%-5 \%$ by $\mathrm{X}$ raydiffraction and thin section identification). Clay typically contains more radioactive crust ${ }^{87} \mathrm{Sr}$, so this is the likely reason for high ${ }^{87} \mathrm{Sr} /{ }^{86} \mathrm{Sr}$ ratios in micrite (McArthur et al, 2001).

3) Compared with micrite, the ${ }^{87} \mathrm{Sr} /{ }^{86} \mathrm{Sr}$ ratio range of the grainstones, ranging from 0.704625 to 0.710405 , was significantly reduced. The average value $(0.706847)$ of ${ }^{87} \mathrm{Sr} /{ }^{86} \mathrm{Sr}$ ratio of the grainstones is nearly the same as that of rudistid shells (0.706812). The data reflect strontium isotope composition of the original seawater, and show high energy condition and little mud composition during deposition, and weak diagenesis during burial, consistent with the fact that Callovian-Oxfordian limestones are still in earlier B stage of mesodiagenesis (Zhang et al, 2010). Furthermore, most grainstones are characterized by weak to moderate cementation, compaction and dissolution. So it is highly favorable to the preservation of original intergranular pores and development of reservoirs. 
4) $\mathrm{The}{ }^{87} \mathrm{Sr} /{ }^{86} \mathrm{Sr}$ ratio of the reef limestone, the limey, silty crystalline dolostone, and the crystalline dolostone and hydrothermal calcite crystals varies over a wide range of $0.704939-0.711870$, well beyond the ${ }^{87} \mathrm{Sr} /{ }^{86} \mathrm{Sr}$ range of the coeval global seawater, and beyond the ${ }^{87} \mathrm{Sr} /{ }^{86} \mathrm{Sr}$ range of micrite which has abnormally high ${ }^{87} \mathrm{Sr} /{ }^{86} \mathrm{Sr}$ ratio. However, their respective average value of the ${ }^{87} \mathrm{Sr} /{ }^{86} \mathrm{Sr}$ ratios is very close, indicating that the dissolution of reef limestone, dolomitization of host rocks and precipitation of hydrothermal calcite are all the reaction products of the same rich- ${ }^{87} \mathrm{Sr}$ diagenetic fluid and the rocks in different diagenetic phases. There are two possible reasons for the highly ${ }^{87} \mathrm{Sr}$-enriched diagenetic fluid: (1) The alteration of micrite with abnormally high ${ }^{87} \mathrm{Sr} /{ }^{86} \mathrm{Sr}$ ratio provided a richer ${ }^{87} \mathrm{Sr}$ composition for the diagenetic fluid. This can be confirmed by the evidence that dolomite and hydrothermal calcite crystals inherited the $\delta^{13} \mathrm{C}$ characteristics of the host limestones. (2) It may be related to radioactive ${ }^{87} \mathrm{Sr}$ from deep fluid. This can be confirmed by the observation that the average ${ }^{87} \mathrm{Sr} /{ }^{86} \mathrm{Sr}$ ratios of the dissolved reef limestone, dolomite and hydrothermal calcite not only increase with increasing diagenetic intensity, but also significantly exceed the ${ }^{87} \mathrm{Sr} /{ }^{86} \mathrm{Sr}$ ratio of micrite. Therefore, it can be determined that besides the strata itself, there must have been a source with higher ${ }^{87} \mathrm{Sr} /{ }^{86} \mathrm{Sr}$; that is, radioactive ${ }^{87} \mathrm{Sr}$ provided by deep clastic strata.

\subsection{Characteristics of vitrinite reflectance and fluid inclusion}

\subsubsection{Characteristics of vitrinite reflectance}

According to the vitrinite reflectance of 14 samples taken from well Sam53-1, the values of Ro is in the range from $0.56 \%-0.74 \%$, with an average value of $0.63 \%$, corresponding to a diagenetic temperature of $80-90{ }^{\circ} \mathrm{C}$ (Liu, 1991). Given that the geothermal gradient is about $3.2^{\circ} \mathrm{C} / 100 \mathrm{~m}$ and the annual average temperature is $15^{\circ} \mathrm{C}$ at present, we could extrapolate that the maximum burial depth of Callovian-Oxfordian strata is $3200-3300 \mathrm{~m}$, consistent with the observation that the carbonates are still in earlier B stage of mesodiagenesis.

\subsubsection{Characteristics of fluid inclusions}

Using the thermometry technology to determine 59 inclusions of six calcite and celestite samples, developed along the high-angle fracture surface and in-filling cracks and cavities, the homogenization temperature was estimated to be in the range $70.1-136.3{ }^{\circ} \mathrm{C}$, with an average temperature of $101{ }^{\circ} \mathrm{C}$, and the salinity $(\mathrm{NaCl})$ from $7.17 \mathrm{wt} \%$ to 23.18 wt $\%$, with an average salinity of $19.6 \mathrm{wt} \%$. The ${ }^{87} \mathrm{Sr}-\mathrm{rich}$ diagenetic fluid has hot brine characteristics, consistent with the calculated result that the salinity index $(Z)$ is higher than 120 (Table 2). In addition, the temperature of the diagenetic fluid determined from fluid inclusions is $15-20{ }^{\circ} \mathrm{C}$ higher than the diagenetic temperature measured by vitrinite reflectance. From the geothermal gradient, it can be inferred that the diagenetic fluid should come from the underlying Middle Jurassic lagoon-swamp coal-bearing clastic strata with a burial depth more than 3200-3300 m. The commonly developed high-angle faults and related fractures that cut through Middle Jurassic coal-bearing strata and CallovianOxfordian carbonate strata are the migration pathway of diagenetic fluid sourced from the underlying middle Jurassic coal-bearing clastic strata. The fluid gained radioactive strontium as it passed through Middle-Lower Jurassic clastic strata, resulting in a diagenetic fluid very rich in ${ }^{87} \mathrm{Sr}$. When the fluid passed into Callovian-Oxfordian carbonates, and the processes of dissolution, dolomitization and calcite precipitation took place, ${ }^{87} \mathrm{Sr}$ was concentrated in the resulting products, therefore the reef limestone, dolomite and hydrothermal calcite, which is closely related with dissolution alteration, have similar and abnormally high ${ }^{87} \mathrm{Sr} /{ }^{86} \mathrm{Sr}$ ratio. Meanwhile, the characteristics of the hot brine were recorded in the hydrothermal calcite and celestite crystals.

\section{Conclusions}

1) The Callovian-Oxfordian strata in Samandepe gas field were deposited during a cycle of sedimentation with sustained transgression-rapid regression that can be correlated with global sea-level change. The reef and shoal reservoir mainly developed in the continuous transgression from $X V m$ to $X V p$, whereas regional, dense gypsum-salt cap rocks developed during the continuous rapid regression from XVac to Early Cretaceous.

2) The diagenetic process of Callovian-Oxfordian carbonates occurred in a closed burial environment. The main diagenesis is still in earlier B stage of mesodiagenesis. The diagenetic fluid was relatively reducing and lacked continental fresh water. Besides temperature, as burial depth increased, reducibility enhancement and homogenization of the diagenetic fluid were also important controlling factors that affected diagenesis.

3) Micrite had higher ${ }^{87} \mathrm{Sr} /{ }^{86} \mathrm{Sr}$ ratios because of higher terrigenous mud content. Grainstones generally maintained ${ }^{87} \mathrm{Sr} /{ }^{86} \mathrm{Sr}$ ratios of coeval seawater; in particular, the ${ }^{87} \mathrm{Sr} /{ }^{86} \mathrm{Sr}$ of the rudistid outer shells was completely consistent with that of the coeval seawater and a strontium isotope age could be calibrated to 157.2 Ma. The reef limestone was strongly altered by diagenesis, dolomite and hydrothermal calcites had abnormally high ${ }^{87} \mathrm{Sr} /{ }^{86} \mathrm{Sr}$ ratios, and ${ }^{87} \mathrm{Sr} /{ }^{86} \mathrm{Sr}$ ratios also tended to simultaneously increase with diagenesis, indicating that diagenesis occurred in the same ${ }^{87} \mathrm{Sr}$-rich diagenetic fluid.

4) A second reason for the high ${ }^{87} \mathrm{Sr}$ values is the hot brine characteristic of the diagenetic fluid of Callovian-Oxfordian carbonates. Fluid originating from the deep strata gained radioactive ${ }^{87} \mathrm{Sr}$ as it migrated through faults and fractures and passed through underlying Middle Jurassic coal-bearing clastic strata and Callovian-Oxfordian carbonates, then formed ${ }^{87} \mathrm{Sr}$-eniched diagenetic fluid. During the processes of dissolution, dolomitization and hydrothermal calcite precipitation, ${ }^{87} \mathrm{Sr}$ concentrated in relevant products, leading to an abnormally high ${ }^{87} \mathrm{Sr} /{ }^{86} \mathrm{Sr}$ ratio.

5) The Callovian-Oxfordian carbonate diagenesis is still relatively weak and is very favourable for the preservation of primary pores in the Samandepe gas field. In such a relatively weak diagenetic environment, reef and shoal limestones typically experience strong dissolution, which enhances the development of dissolution pores, holes and fractures. 
Therefore, identifying the favorable reef and shoal facies should be the main basis for the reservoir prediction and evaluation.

\section{References}

Derry L A, Brasier M D, Corfield R M, et a1. Sr and C isotopes in Lower Cambrian carbonates from the Siberian craton: A paleoenvironmental record during the 'Cambrian explosion'. Earth and Planetary Science Letters. 1994. 128: 671-681

Emrich K, Ehhalt D H and Vogel J C. Carbon isotope fractionation during the precipitation of calcium carbonate. Earth and Planetary Science Letters. 1970. 8(5): 363-369

Green D G and Mountjoy E W. Fault and conduit controlled burial dolomitization of the Devonian West-central Alberta Deep Basin. Bulletin of Canadian Petroleum Geology. 2005. 53(2): 101-129

Hu Z G, Zheng R C, Zhou G, et al. Dolostone genesis of Huanglong Formation of Carboniferous in Linshui of eastern Sichuan - northern Chongqing area. Acta Petrologica Sinica. 2008. 24(6): 1369-1378 (in Chinese)

Huang S J, Pei C R, Hu Z W, et al. Strontium concentration, isotope composition and dolomitization fluids in the Feixianguan Formation of Triassic, Eastern Sichuan of China. Acta Petrologica Sinica. 2006 22(8): 2123-2132 (in Chinese)

Jiao W W, Yang H J, Zhao Y, et al. Application of trace elements in the study of oil-source correlation and hydrocarbon migration in the Tarim Basin, China. Energy, Exploration \& Exploitation. 2010. 28(6): 451-466

Kaufman A J, Knoll A H, Awramik S M, et al. Biostratigraphic and chemostratigraphic correlation of Neoproterozoic sedimentary successions: Upper Tindir Group, northwestern Canada, as a test case. Geology. 1992. 20: 181-185

Keith M L and Weber J N. Carbon and oxygen isotopic composition of selected limestones and fossils. Geochimica et Cosmochimica Acta. 1964. 1786-1816

Li R F and Liu B P. Application of carbon and oxygen isotopes to carbonate sequence stratigraphy: analysis of mapping formation, southern Guizhou province. Earth Science-Journal of China University of Geosciences. 1996. 21(3): 261-266 (in Chinese)

Li R X, Wei J Y, Xiao J Fi, et al. Response of carbon and oxygen isotopic geochemistry to transgressive systems tract: An example from Triassic stratigraphy in southwestern Guizhou Province. Journal of Earth Sciences and Environment. 2007. 29(1): 1-5, 21 (in Chinese)

Liu J Q, Jia B J, Yang P, et al. The application of carbon, oxygen and strontium isotopes to the study of middle-upper Jurassic sequence stratigraphy in Longweicuo area, Qiangtang Basin. Acta Geoscientica Sinica. 2007. 28(3): 253-260 (in Chinese)

Liu Y F. Laboratory methods of sedimentary rocks. Beijing: Geological Publishing House. 1991 (in Chinese)

McArthur J M, Howarth R J and Bailey T R. Strontium isotope stratigraphy: LOWESS Version 3: Best fit to the marine Sr-isotope curve for 0-509 Ma and accompanying look-up table for deriving numerical age. The Journal of Geology. 2001. 109: 155-170

Meisel T, Krähenbühl U and Nazarov M A. Combined osmium and strontium isotopic study of the Cretaceous-Tertiary boundary at Sumbar, Turkmenistan: A test for an impact vs. a volcanic hypothesis. Geology. 1995. 23(4): 313-316

Price G D and Gröcke D R. Strontium-isotope stratigraphy and oxygenand carbon-isotope variation during the Middle Jurassic-Early Cretaceous of the Falkland Plateau, South Atlantic. Palaeogeography, Palaeoclimatology, Palaeoecology. 2002. 183(3-4): 209-222

Scholle P A and Arthur M A. Carbon isotopic fluctuation in Cretaceous pelagic limestone: Potential stratigraphic and petroleum exploration tool. AAPG Bulletin. 1980. 64: 67-87

Shi J N, Zheng R C, Feng Q P, et al. Fluid origin of burial dolomitization and hydrocarbon accumulation model of backward charging in Changxing formation, NE Sichuan basin. Natural Gas industry. 2009. 29(3): 5-8 (in Chinese)

Spooner E. The strontium isotope composition of seawater and seawateroceanic crust interaction. Earth and Planetary Science Letters. 1976. 31: $167-174$

Swart P K, Cantrell D L, Westphal H, et al. Origin of dolomite in the Arab-D reservoir from the Ghawar field, Saudi Arabia: Evidence from petrographic and geochemical constraints. Journal of Sedimentary Research. 2005. 75(3): 476-491

Veizer $J$ and Hoefs $J$. The nature of $\mathrm{O}^{18} / \mathrm{O}^{16}$ and $\mathrm{C}^{13} / \mathrm{C}^{12}$ secular trends in sedimentary carbonate rocks. Geochimica et Cosmochimica Acta. 1976. 40(11): 1387-1395

Veizer J, Ala D, Azmy K, et al. ${ }^{87} \mathrm{Sr} /{ }^{86} \mathrm{Sr}$, delta ${ }^{13} \mathrm{C}$ and delta ${ }^{18} \mathrm{O}$ evolution of Phanerozoic seawater. Chemical Geology. 1999. 161(1-3): 59-88

Veizer J, Fritz P, Jones B, et al. Geochemistry brachiopods: Oxygen and carbon isotopic records of Paleozoic oceans. Geochimica et Cosmochimica Acta. 1986. 50(8): 1679-1696

Yao J L, Wang B Q, Wang Y, et al. Geochemical characteristics of dolomites in lower Ordovician Majiagou Formation, Ordos Basin. Acta Sedimentologica Sinica. 2009. 27(3): 381-399 (in Chinese)

Zeng J H, Xu T W, Sun Z Q, et al. Origin of paleofluids in Dabashan foreland thrust belt: Geochemical evidence of ${ }^{13} \mathrm{C},{ }^{18} \mathrm{O}$ and ${ }^{87} \mathrm{Sr} /{ }^{86} \mathrm{Sr}$ in Veins and Host rocks. Acta Geologica Sinica (English Edition). 2010. 84(5): 1239-1255

Zeng Y F and Xia W J. Sedimentary Petrography. Beijing: Geological publishing house. 1986. 165-170 (in Chinese)

Zhang B, Zheng R C, Liu H N, et al. Characteristics of Carbonate Reservoir in Callovian-Oxfordian of Samandepe Gasfield, Turkmenistan. Acta Geologica Sinica. 2010. 84(1): 117-125 (in Chinese)

Zhang C J, Zheng M P, Alexander Prokopenko, et al. High-resolution records of the holocene paleoenvironmental variation reflected by carbonate and its isotopic compositions in Bosten Lake and response to glacial activities. Acta Geologica Sinica (English Edition). 2009. 83(6): 1101-1115

Zheng R C and Shi J N. Comparative study on geochemical behaviors of dolomite reservoirs in north-east Sichuan basin. Natural Gas industry. 2008. 28(11): 16-21 (in Chinese)

Zheng R C, Gen W, Luo P, et al. Genesis of dolostone reservoir of Feixianguan Formation in Lower Triassic of northeast Sichuan Basin. Acta Petrologica Sinica. 2008a. 29(6): 815-821 (in Chinese)

Zheng R C, Hu Z G, Feng Q P, et al. Genesis of dolomite reservoir of the Changxing formation of upper Permian, northeast Sichuan basin. Journal of Mineralogy and Petrology. 2007. 27(4): 78-84 (in Chinese)

Zheng R C, Hu Z G, Zheng C, et al. Stable isotopic geochemical characteristics of paleokarst reservoirs in Huanglong formation in northern Chongqing-eastern Sichuan area. Earth Science Frontiers. 2008b. 15(6): 303-311 (in Chinese)

Zheng R C, Zheng C, Hu Z G, et al. Strontium isotopic geochemical behaviors of the Carboniferous palaeo-karst reservoirs in east Sichuan basin. Natural gas industry. 2009. 29(7): 1-5 (in Chinese)

Zheng R C, Chen H D, Zhang S N, et al. Stable isotopic characteristics of karst-reservoirs in Huanglong formation from eastern Sichuan. Earth Science-Journal of China University of Geosciences. 1997. 22(4): 424-428 (in Chinese)

(Edited by Zhu Xiuqin) 